\section{Evaluation of parathyroid function and mineral metabolism in psychiatric patients using lithium salts}

\author{
Avaliação da função paratireoidiana e metabolismo mineral \\ em pacientes psiquiátricos usuários de sais de lítio
}

Thiago Costa de Oliveira', Ivo Alves de Campos Neto', Manuel

Hermínio de Aguiar-Oliveira' ${ }^{\prime}$, Francisco de Assis Pereira ${ }^{1}$
1 Departament of Medicine, Universidade Federal de Sergipe (UFS), Aracaju, SE, Brazil nized calcium, inorganic phosphorus, alkaline phosphatase, albumin, parathyroid hormone (PTH), urea, creatinine, 25-hydroxy-vitamin D and lithium of 35 patients diagnosed with bipolar disorder in use of lithium carbonate (LC) for at least one year (Lithium Group - LG) and 35 healthy subjects (Control Group - CG). Results: The LG and CG were matched by sex and age. There was only statistic difference in relation to the levels of PTH and ionized calcium, with $p$ $<0.004$ and $p<0.03$, respectively. Secondary form of hyperparathyroidism (HPT) was found in eight $(22.8 \%)$ LG patients and in none of the CG. There was no correlation between lithemia, usage time and dosage of LC. Conclusion: Our data demonstrate that lithium may create an imbalance in the parathyroid axis, characterized by elevated levels of PTH. Arq Bras Endocrinol Metab. 2014;58(6):619-24

\section{Keywords}

Lithium; parathyroid; mineral metabolism; hyperparathyroidism

\section{RESUMO}

Objetivo: Avaliar a função paratireoidiana e o metabolismo mineral em pacientes psiquiátricos usuários de sais de lítio. Materiais e métodos: Foram avaliados os níveis séricos de cálcio total, cálcio iônico, fósforo inorgânico, fosfatase alcalina, albumina, paratormônio (PTH), ureia, creatinina, 25-hidroxivitamina $\mathrm{D}$ e lítio de 35 pacientes diagnosticados com transtorno afetivo bipolar usuários de carbonato de lítio $(\mathrm{CL})$ há pelo menos um ano (Grupo Lítio - GL) e 35 indivíduos saudáveis (Grupo Controle - GC). Resultados: O GL e o GC foram pareados por sexo e idade. Somente se observou diferença estatística em relação aos níveis de PTH e cálcio iônico, com $p<0,004$ e $p<0,03$, respectivamente. Hiperparatireoidismo secundário foi encontrado em oito $(22.8 \%)$ pacientes do GL e em nenhum do GC. No GL, não houve correlação entre litemia, tempo de uso e posologia do CL. Conclusão: Nossos dados demonstram que o lítio pode suscitar um desequilíbrio no eixo paratireoideano, caracterizado por níveis elevados de PTH. Arq Bras Endocrinol Metab. 2014;58(6):619-24

\section{Descritores}

Lítio; paratireoide; metabolismo mineral; hiperparatireoidismo
Correspondence to:

Francisco de Assis Pereira St. José Freire, 644 490020-410 - Aracaju, SE, Brazil frasp@terra.com.br

Received on Sept/7/2013 Accepted on May/12/2014 DOI: 10.1590/0004-2730000002983

\section{INTRODUCTION}

$\mathrm{A}$ bout six decades, lithium salts were introduced as medical treatment due to their ability to modulate and stabilize mood in psychiatric patients with affective disorders $(1,2)$. The use of lithium $(\mathrm{Li})$ is the most effective long-term therapy for affective disorders, such as bi- polar affective disorder (BAD), as it protects users against humor fluctuations reducing manic and depressive phases in this illness and, consequently, reduces mortality and the risk of suicide (3-5). Despite recent advances in pharmacological treatment of psychiatric disorders in Brazil, Li remains as an effective and low cost alternative drug, 
being provided free of charges by the National Health System in the form of Lithium Carbonate (LC) $(6,7)$.

$\mathrm{Li}$ has a very narrow therapeutic window, being clinically effective with plasma concentrations of 0.6$1.5 \mathrm{mEq} / \mathrm{L}$ (equivalent to $600-1,500 \mathrm{mg}$ of LC) and producing many toxic effects when above these values, thus justifying the importance of quarterly to semiannual monitoring of the serum levels of patients using Li (8-11).

When serum concentrations are much higher than those recommended, one can develop Li intoxication, a situation favored by certain risk factors, such as higher age, overdose, chronic renal failure, nephrotic syndrome, cirrhosis, heart failure, diabetes insipidus induced by Li therapy and the use of anti-inflammatory drugs, angiotensin-converting enzyme inhibitors and thiazide diuretics $(12,13)$.

Chronic use of Li can lead to a mild hyperparathyroidism (HPT), which is usually reversible after the discontinuation of the therapy (10). In the parathyroid glands, Li acts by inhibiting the cAMP second messenger system, which triggers a compensatory mechanism that results in the elevation of PTH, thus increasing the plasma levels of calcium $(1,10)$.

Many in vivo studies have shown that $\mathrm{Li}$ interferes with the dynamics of PTH secretion by increasing the sensitivity threshold of the parathyroid calcium receptor and inhibiting renal calcium excretion (14). By shifting the $\mathrm{PTH} /$ calcium curve for the right, higher serum calcium levels are necessary to inhibit the secretion of $\mathrm{PTH}$, thereby raising the levels of this hormone and calcium $(10,12,15)$. The changes in the body resulting from HPT induced by Li may be the same as classically originated by primary hyperparathyroidism (PHP), even though it is known that the vast majority of cases evolve with few clinical signs of the mineral metabolism imbalance, except for kidney stone formation, which is the most frequent situation found $(16,17)$.

In $\mathrm{Li}$ users who have been using it for at least 10 years, the prevalence of HPT was observed in approximately $10-15 \%$, being higher in women (4:1), with the occurrence of both hyperplasia and adenomas of the parathyroid glands $(18,19)$. In confirming diagnoses of lithium-associated hyperparathyroidism, therapeutic decisions should be individualized, taking as an initial choice suspension of $\mathrm{Li}$ in symptomatic patients. In persistence of symptoms, parathyroidectomy is required with recommended bilateral neck exploration, in order to minimize the risk of disease recurrence $(20,21)$.
The aim of this study was to evaluate parathyroid function and mineral metabolism in psychiatric patients using lithium salts, confirming the need for better control of these parameters in clinical practice.

\section{MATERIALS AND METHODS}

This is a cross-sectional, descriptive study, with a quantitative approach and convenience sampling of 35 patients diagnosed with $\mathrm{BAD}$, current using $\mathrm{LC}$ as treatment and with clinical follow-up in the following psychiatry public services in the city of Aracaju (SE): University Hospital of the Federal University of Sergipe (HU-UFS), Francisco Fonseca Health Center (CSFF) and Jael Patrício de Lima Psychosocial Care Center III (CAPS-III). The research project was submitted for review and approval to the University Hospital Research Ethics Committee of the Federal University of Sergipe, and received the CAEE number 09436112.4.0000.5546. The Informed Consent term was signed after all participants had received detailed and specific information related to the purposes and methods of this study.

The study included two groups: control group (CG), composed of 35 healthy individuals, and the Lithium Group (LG), comprising 35 patients under treatment with LC, matched for age and sex. The inclusion criterion for the LG was the continued use of LC for at least one year. Exclusion criteria for both groups were age (under 18); cancer, parathyroid and/or thyroid dysfunction, chronic renal failure and nephrotic syndrome, pregnancy, use of drugs that interfere with the metabolism of calcium (thiazide diuretics, inhibitors of angiotensin converting enzyme, anti-inflammatory drugs and calcium supplementation), and the refuse to participate in the study.

Information about patients were obtained during the period between December 2012 and May 2013, from the analysis of charts and the fill out of a questionnaire containing the name, gender, age, skin color, weight, height, body mass index (BMI), marital status, education, profession, county of origin, psychiatric diagnosis that motivated the use of lithium as treatment, associated pathologies (including current medications and treatments performed), daily dose and duration of use of LC and other medications. Initially, the selected patients underwent an interview to complete the study questionnaire and then they were asked to go to the laboratory of clinical analysis from HU-UFS and were told to fast 10-12 hours for blood test. 
The laboratory parameters studied were: PTH, by the chemiluminescence method (reference value: 11$67 \mathrm{pg} / \mathrm{mL}$ ) - Immulite 2000 Siemens Healthcare Diagnostics Inc., USA; total calcium, by the calorimetric method (reference value: $8.8-11.0 \mathrm{mg} / \mathrm{dL}$ ); ionized calcium, by the fluorimetry method (reference value: $4.6-5.4 \mathrm{mg} / \mathrm{dL}$ ); inorganic phosphorus, by the phosphomolybdate method (reference value: 2.5-4.5 $\mathrm{mg} / \mathrm{dL}$ ); albumin, by the bromocresol green method (reference value: $3.5-5.0 \mathrm{~g} / \mathrm{dL}$ ); alkaline phosphatase, kinetic method (reference value: $27-100 \mathrm{U} / \mathrm{L}$ ); creatinine, enzymatic method (reference value: 0.7-1.2 $\mathrm{mg} / \mathrm{dL}$ ); urea, calorimetric method (reference value: 15-45 mg/dL) - Vitros 5.1 FS, Johnson \& Johnson Company, Canada; 25-hydroxyvitamin D, chemiluminescence method (normal: 30-40 ng/mL) - Architect il000 SR, Abbott Diagnostics, USA; and lithium, by the ion selective electrode method (reference value: 0.6-1.2 mEq/L) - 9180 Electrolyte Analyzer, Roche Diagnostics, Germany.

For statistical analysis of the obtained results, we used the GraphPad Prism, version 12.0 for Windows 2012 (San Diego, CA, USA). Numerical variables were described as mean and standard deviation. Either the chi-square test or Fisher's exact test was used to evaluate categorical variables. We used Student's t test for continuous variables analysis, if they had normality characteristics, and otherwise, a nonparametric Mann-Whitney test was applied. We used the Person's coefficient of variation for parametric variables and Spearman to correlate nonparametric variables. The level of significance for rejecting the null hypothesis was $5 \%(\mathrm{p}<0,05)$.

\section{RESULTS}

Of the 41 patients interviewed to be included in the LG, 35 were eligible for the study. Four patients were excluded because of lack of continuous use of the drug and two for refusing to participate in the research.

The control group was composed of 21 women (60\%) and 14 men (40\%), whereas 22 women $(62.8 \%)$ and 13 men $(37.2 \%)$ comprised the LG. The mean chronological age was $47.5 \pm 11.7$ years (ranging from 25 to 66 ) in CG and $45.9 \pm 12.2$ years (ranging from 26 to 65) in LG. The serum Li level found in the $\mathrm{LG}$ patients was $0.56 \pm 0.2 \mathrm{mEq} / \mathrm{L}$ (ranging from 0.19 to $0.92 \mathrm{mEq} / \mathrm{L}$ ). The skin color, weight, height, BMI of participants, the treatment duration and the
LC current dosage are presented in table 1. Neither there was correlation between vitamin D levels and weight nor between vitamin D levels and BMI.

The serum level of urea and creatinine, renal function markers, showed no statistical difference among the studied groups, the same occurring with the blood levels of albumin, total calcium, alkaline phosphatase, inorganic phosphorus, 25-hydroxyvitamin $\mathrm{D}$ and lithium, parameters presented in table 2 .

The plasma concentrations of both PTH and ionized calcium in LG were higher than in the CG, presenting statistical difference: PTH (Figure 1) - CG = $49.2 \pm 11.0 \mathrm{pg} / \mathrm{dL}$ versus $54.9 \pm 24.2 \mathrm{pg} / \mathrm{dL}(\mathrm{p}<$ 0.004 ) for LG; ionized calcium (Figure 2 ) - $\mathrm{CG}=4.2$ $\pm 0.4 \mathrm{mg} / \mathrm{dL}$ versus $\mathrm{LG}=4.4 \pm 0.4 \mathrm{mg} / \mathrm{dL}(\mathrm{p}<0.03)$.

The elevation of PTH serum levels features HPT, a clinical condition found in eight patients $(22.8 \%)$ of the LG and in none in the CG. Despite higher levels of PTH, these patients had serum calcium within the normal range. No correlations were identified between the serum Li level, usage time and dosage of LC as well as between levels of vitamin D, weight and BMI. There were not correlations of calcium and PTH as well as vitamin D and PTH.

Table 1. Clinical and demographic data of the Control Group (CG) and the Lithium Group (LG)

\begin{tabular}{lccc}
\hline Variables & $\begin{array}{c}\text { CG } \\
(\mathbf{n = 3 5 )}\end{array}$ & $\begin{array}{c}\text { LG } \\
(\mathbf{n = 3 5 )}\end{array}$ & p value \\
\hline Skin color $(\mathrm{W}: \mathrm{NW})$ & $16: 19$ & $18: 17$ & 0.95 \\
Weight in $\mathrm{kg}(\mathrm{X} \pm \mathrm{SD})$ & $64.7 \pm 12.3$ & $64,6 \pm 12,93$ & 0.97 \\
Height in $\mathrm{m}(\mathrm{X} \pm \mathrm{SD})$ & $1.56 \pm 0.08$ & $1,57 \pm 0,05$ & 0.34 \\
BMl in $\mathrm{kg} / \mathrm{m}^{2}(\mathrm{X} \pm \mathrm{SD})$ & $26.7 \pm 4.9$ & $27,0 \pm 4,8$ & 0.46 \\
Use time in years $(\mathrm{X} \pm \mathrm{SD})$ & $\mathrm{NR}$ & $6,1 \pm 4,2$ & $\mathrm{NR}$ \\
Current dosage in $\mathrm{mg} /$ day $(\mathrm{X} \pm \mathrm{SD})$ & $\mathrm{NR}$ & $702.9 \pm 266.8$ & $\mathrm{NR}$ \\
\hline
\end{tabular}

W: white, NW: not white, NR: not rated.

Table 2. Laboratory data of the Control Group (CG) and the Lithium Group (LG)

\begin{tabular}{lccc}
\hline Variables & $\begin{array}{c}\text { CG } \\
(\mathbf{X} \pm \mathbf{S D})\end{array}$ & $\begin{array}{c}\text { LG } \\
(\mathbf{X} \pm \mathbf{S D})\end{array}$ & p value \\
\hline Total calcium (mg/dL) & $8.7 \pm 0.4$ & $9.0 \pm 0.8$ & $<0.1$ \\
Inorganic phosphorus (mg/dL) & $3.8 \pm 0.4$ & $3.7 \pm 0.6$ & 0.5 \\
Albumin (mg/dL) & $4.4 \pm 0.4$ & $4.4 \pm 0.5$ & 0.7 \\
Alkaline phosphatase (U/L) & $66.1 \pm 21.0$ & $76.1 \pm 28.1$ & $<0.1$ \\
Urea (mg/dL) & $29.4 \pm 5.5$ & $26.7 \pm 8.0$ & $<0.09$ \\
Creatinine (mg/dL) & $0.7 \pm 0.2$ & $0.7 \pm 0.2$ & 0.9 \\
25-hidroxy vitamin D (ng/mL) & $41.1 \pm 7.0$ & $40.7 \pm 32.4$ & $<0.06$ \\
\hline
\end{tabular}




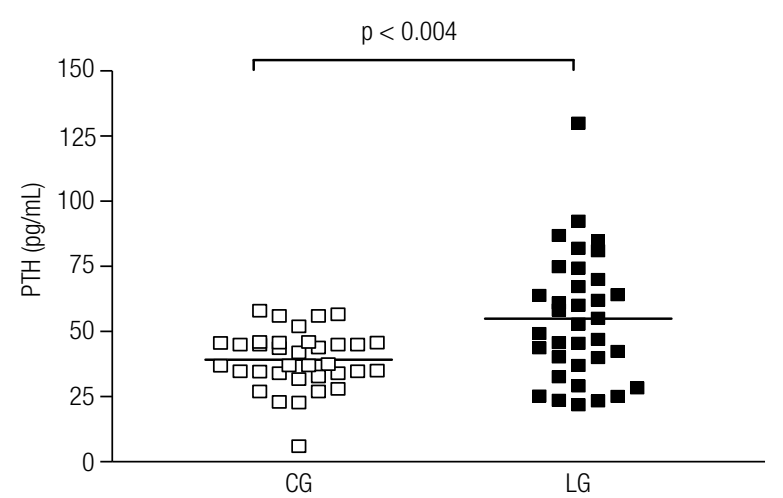

Figure 1. Plasma concentration of parathyroid hormone (PTH) of the control group (CG) and the Lithium Group (LG).

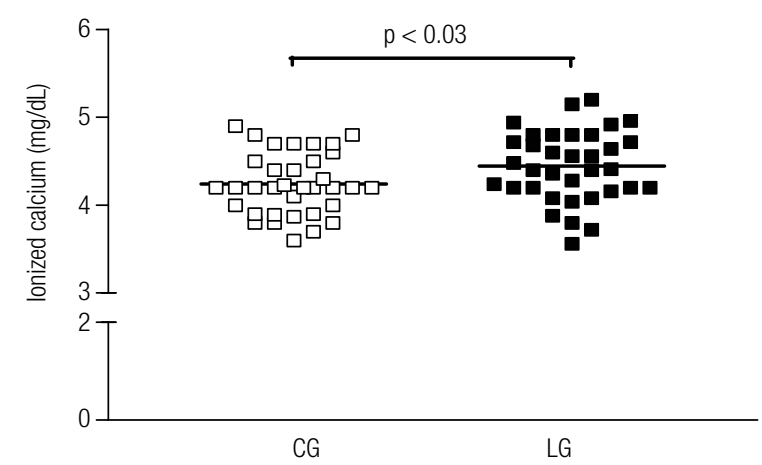

Figure 2. Plasma concentration of ionized calcium of the control group (CG) and the Lithium Group (LG).

Among patients in the LG, it was noted that nine patients had systemic hypertension and six had diabetes mellitus. These patients had these diagnoses prior to the use of LC. Of the eight participants who had high levels of PTH, four had at least one of these comorbidities.

\section{DISCUSSION}

The HPT is a clinical syndrome characterized by excessive function of the parathyroid glands, resulting in persistent PTH hypersecretion and its consequences in the body. It can be associated with elevated serum calcium levels or within the normal range (22). The PHP has a prevalence of approximately $1 \%$ in the adult population, with equal distribution between the genders, doubling after the age of 55 , being, in this age group, two to three times more common in women than in men (23).

Currently, the signs and symptoms of PHP are becoming rarer, with $80-85 \%$ of patients being asymptomatic. In this medical condition, PTH levels are slightly increased and calcium level, when high, is usually only up to $1.0 \mathrm{mg} / \mathrm{dL}$ above the upper normal limit. Hypophosphatemia, found in the classic form of PHP, is uncommon in patients with asymptomatic disease (24). At the diagnosis of PHP, the main cause of hypercalcemia in patients with normal renal function, it is essential to observe the level of calcium in association with PTH levels, as there are situations in which, despite the normocalcemia, there is hormone elevation, as found in normocalcemic PHP, a non-indolent condition, similar to an initial PHP (25).

The literature is unison in saying that, by decreasing the calcium sensitivity in the parathyroid, $\mathrm{Li}$ disrupts the bone-parathyroid endocrine axis and triggers disorders in calcium homeostasis. This could lead to a classic PHP and even to a normocalcemic HPT or hypercalcemia without PTH elevation $(9,26,27)$. Both in vitro studies and in vivo studies in healthy volunteers demonstrated direct action of lithium on parathyroid cells in releasing intact PTH (28). Lithium can shift the set point of calcium-sensing receptors (CaSR) in parathyroid cells, leading onto excess release of PTH $(28,29)$. In this work, we observed serum PTH elevated in $22.8 \%$ of patients using LC, confirming a disbalance in the physiology of the parathyroid glands caused by Li. According to data reported in most large series, the ratio for HPT in Li users between females and males is $4: 1$ $(18,30,31)$. In our study, the ratio found was of 3 women for 1 man.

Despite the elevation of PTH in some patients in the LG, the levels of total calcium and ionized calcium of these patients remained within the normal range. In LG, it was noted, however, that the mean plasma concentrations of ionized calcium was higher compared with the CG (Figure 2). This finding is in agreement with several literature reports and it may be explained by the fact that the ionized calcium is more sensitive than the total calcium for detection of hypercalcemia in patients treated with $\mathrm{Li}(32,33)$.

According to the data obtained from the medical records, all patients in the LG stayed euthymic for more than six months, despite the fact that only 16 (45.7\%) were with Li levels within the therapeutic range. Of the eight LG patients who presented increased PTH, five had normal Li serum levels and the others had Li levels below the expected. This suggests that the HPT induced by Li was not re- 
lated to the values of $\mathrm{Li}$ in the blood, fact that could be, possibly, explained by an intrinsic property of the drug responsible for the imbalance of the parathyroid endocrine axis and not being related to the given dose or its serum levels. This condition is in agreement with the explanation proposed by some studies, which say that the HPT induced by Li has no relation to the given therapeutic dose, but rather with the presence of the medication in the body $(34,35)$. The duration of the treatment increases the incidence of this clinical condition due to the cumulative power that Li has on the body $(19,36)$.

Lithium, an inhibitor of glycogen synthase kinase 3 (GSK3), is widely used for the treatment of mood disorders. Lithium treatment significantly increased renal GSK3 phosphorylation, enhanced serum ADH and FGF23 concentrations, downregulated renal Klotho expression, stimulated renal calcium and phosphate excretion, and decreased serum 1,25(OH)2D3 and phosphate concentrations (37). Since $\mathrm{Li}$ is not bound to serum proteins, it is freely filtered by the kidneys and its elimination depends on the glomerular filtration rate. Consequently, Li blood levels and undesirable effects caused by Li are directly related to renal function $(9,10)$. The participants of this study were assessed by measurements of blood urea and creatinine, which were within normal limits. Such fact excluded the possibility that the HPT, found in some patients, would have been induced by renal failure (secondary HPT).

Regarding the levels of phosphorus, alkaline phosphatase and 25-hydroxyvitamin D, there was no statistical difference compared to the CG. This result can be related to the presence of normocalcemic HPT, in which laboratory abnormalities are restricted to changes in PTH levels. These data are similar to those found by Khoury and cols. (33).

In our study, half of the patients with high PTH had either hypertension or diabetes mellitus. According to the literature, only diabetes mellitus has a positive relation with the use of lithium salts, since Li has an inhibitor effect on the insulin secretion induced by glucose due to mechanisms related to the influx of calcium in pancreatic beta cells $(3,10)$. There was no correlation between the use of LC and development of these comorbidities in patients of LG, since such diagnoses were made prior to initiation of treatment with $\mathrm{Li}$.

Limitations of this study were the non-evaluation of bone turnover markers, urinary calcium levels, bone mineral density and the lack of an ultrasound evalu- ation of the kidneys and urinary tract of the patients studied in both groups. Although, Zamani and cols. found that patients on maintenance therapy with lithium had higher bone mineral density in both the lumbar spine and the proximal femur and lower serum total alkaline phosphatase (ALP) and C-telopeptide (CTX) and osteocalcin than normal controls. The lower serum osteocalcin, CTX and ALP suggest decreased bone remodeling contrary to what is seen in primary hyperparathyroidism, which is associated with accelerated skeletal turnover and increased osteocalcin and markers of bone resorption (38).

Guidelines recommendations for treatment with $\mathrm{Li}$ in patients with $\mathrm{BAD}$ do not mention monitoring of parathyroid function, what appears to be an important omission in the follow-up of these individuals due to the high absolute risk of developing mild, reversible hyperparathyroid state $(15,38,39)$. Thus, our data suggest that the use of lithium salts, as an alternative therapy in psychiatric patients suffering from $\mathrm{BAD}$, must be accompanied by periodic assessments of mineral metabolism in an attempt at early detection of possible imbalances in parathyroid endocrine axis, considering that $22.8 \%$ of patients using $\mathrm{Li}$ had elevated serum levels of PTH.

Disclosure: no potential conflict of interest relevant to this article was reported.

\section{REFERENCES}

1. Saunders BD, Saunders EFH, Gauger PG. Lithium therapy and hyperparathyroidism: an evidence-based assessment. World J Surg. 2009;33:2314-23.

2. Price $\mathrm{LH}$, Heninger GR. Lithium in the treatment of mood disorders. N Engl J Med. 1994;331(9):591-8.

3. Mcknight RF, Adida M, Budge K, Stockton S, Goodwin GM, Geddes JR. Lithium toxicity profile: a systematic review and meta-analysis. Lancet. 2012;379:721-8.

4. Rosa AR, Kapczinski F, Oliva R, Stein A, Barros HMT. Monitoramento da adesão ao tratamento com lítio. Rev Psiq Clín. 2006;33(5):249-61.

5. Cipriani A, Pretty H, Hawton K, Geddes JR. Lithium in the prevention of suicidal behaviour and all-cause mortality in patients with mood disorders: a systematic review of randomized trials. Am J Psychiatry. 2005;162:1805-19.

6. Martin LNC, Kayath MJ. Abordagem clínico-laboratorial no diagnóstico diferencial de hipercalcemia. Arq Bras Endocrinol Metab. 1999;43(6):472-9.

7. Ministério da Saúde. Profissional e Gestor - Medicamentos Relação Nacional de Medicamentos Essenciais (RENAME 2012). Avaliable at: http://www.saude.gov.br. Accessed on: Jul 3, 2013.

8. Rang HP, Dale MM, Ritter JM, Flower RJ. Rang \& Dale Farmacologia. 6th. Rio de Janeiro: Elsevier. 2007;557-74. 
9. Collins N, Barnes TR, Shingleton-Smith A, Garret D, Paton C. Standards of lithium monitoring in mental health trusts in the UK. BMC Psychiatry. 2010;10:80.

10. Giusti CF, Amorim SR, Guerra RA, Portes ES. Endocrine disturbances related to the use of lithium. Arq Bras Endocrinol Metab. 2012;56(3):153-8.

11. Mármol F. Litio: 55 años de historia en el tratamiento del trastorno bipolar. Med Clin (Barc). 2005;127(5):189-95

12. Oliveira JL, Silva Júnior GB, Abreu KLS, Rocha NA, Franco LFLG, Araújo SMHA, et al. Nefrotoxicidade por lítio. Rev Assoc Med Bras. 2010;56(5):600-6.

13. Timmer RT, Sands JM. Lithium intoxication. J Am Soc Nephrol. 1999;10:666-74.

14. Bhuvaneswar CG, Baldessarini RJ, Harsh VL, Alpert JE. Adverse endocrine and metabolic effects of psychotropic drugs. CNS Drugs. 2009;23(12):1003-21.

15. MakTWL, Shek C, Chow C, Wing Y, Lee S. Effects of lithium therapy on bone mineral metabolism: a two-year prospective longitudinal study. J Clin Endocrinol Metab. 1998;83(11):3857-9.

16. Marx SJ. Hyperparathyroid and hyperparathyroid disorders. $\mathrm{N}$ Engl J Med. 2000;343(25):1863-75.

17. Grüfeld JP, Rossier BC. Lithium nephrotoxicity revisited. Nat Rev Nephrol. 2009;5:270-6.

18. Hundley JC, Woodrum DT, Saunders BD, Doherty GM, Gauger PG. Revisiting lithium-associated hyperparathyroidism in the era of intraoperative parathyroid hormone monitoring. Surgery. 2005;138:1027-31.

19. Szalat A, Mazeh H, Freund HR. Lithium-associated hyperparathyroidism: report of four cases and review of the literature. Eur $\mathrm{J}$ Endocrinol. 2009;160(2):317-23.

20. Nair CG, Menon R, Jacob P, Babu M. Lithium-induced parathyroid dysfunction: A new case. Indian. J Endocrinol Metab. 2013;17(5):930-2.

21. Skandarajah AR, Palazzo FF, Henry JF. Lithium-associated hyperparathyroidism: surgical strategies in the era of minimally invasive parathyroidectomy. World J Surg. 2011;35:2432-9.

22. Prospero JD, Baptista PPR, Amary MFC, Santos PPC. Paratireoides: estrutura, funções e patologia. Acta Ortop Bras. 2008;17(2):53-7.

23. Gómez JMC. Evaluación diagnóstica e diagnóstico diferencial del hiperparatiroidismo primário. Endocrinol Nutr. 2009;56(Supl 1):14-9.

24. Bilezikian JP, Silverberg SJ. Asymptomatic primary hyperparathyroidism. N Engl J Med. 2004;350(17):1746-51.

25. Marques TF, Vasconcelos R, Diniz E, Rêgo D, Griz L, Bandeira F. Normocalcemic primary hyperparathyroidism in clinical practice: an indolent condition or a silent threat? Arq Bras Endocrinol Metab. $2011 ; 55(5): 314-7$.

26. Komatsu M, Shimizu H, TsurutaT, Kato M, FushimiT, Inoue K, et al. Effect of lithium on serum calcium level and parathyroid function in maniac-depressive patients. Endocr J. 1995;42:691-5.

27. Gregoor PS, Jong GM. Lithium hypercalcemia, hyperparathyroidism and cinacalcet. Kidney Int. 2007;71:470.

28. Kusalic M, Engelsmann F. Effect of lithium maintenance therapy on thyroid and parathyroid function. J Psychiatry Neurosci. 1999;24:227-33.

29. Haden ST, Stoll AL, Mccormick S, Scott J, Fuleihan GE. Alterations in parathyroid dynamics in lithium-treated subjects. J Clin Endocrinol Metab. 1997;82:2844-8.

30. Carchman E, Ogilvie J, Holst J,Yim J, Carty S. Appropriate surgical treatment of lithium-associated hyperparathyroidism. World J Surg. 2008;32:2195-9.

31. Awad SS, Miskulin H, Thompson N. Parathyroid adenomas versus four-gland hyperplasia as the cause of primary hyperparathyroidism in patients with prolonged lithium therapy. World $\mathrm{J}$ Surg. 2003;27:486-8.

32. Adegboyega PA, Okorodudu AO. Intracellular ionized calcium and increasing doses of lithium chloride therapy in healthy Sprague-Dawley rats. Pharmacol Biochem Behav. 1994;49(4):1087-91.

33. Khoury AE, Petterson U, Kallner G, Aberg-Wistedt A, Stain-Malmgren R. Calcium homeostasis in long-term lithium-treated women with bipolar affective disorder. Prog Neuropsychopharmacol Biol Psychiatry. 2002;26(6):1063-9.

34. Rothman M. Acute hyperparathyroidism in a patient after initiation of lithium therapy. Am J Psychiatry. 1982;139:362-3.

35. Seely EW, Moore TJ, Leboff MS, Brown EM. A single dose of lithium carbonate acutely elevates intact parathyroid hormone levels in humans. Acta Endo (Buc). 1989;121:174-6.

36. Bendz H, Sjodin I, Toss G, Berglund K. Hyperparathyroidism and long-term lithium therapy - a cross-sectional study and the effect of lithium withdrawal. J Intern Med. 1996;240:357-65.

37. Fakhri H, Pathare G, Fajol A, Zhang B, Bock T, Kandolf R, et al. Pflugers Arch. 2014;66(3):467-75.

38. Zamani A, Omrani GR, Nasab MM. Lithium's effect on bone mineral density. Bone. 2009;44:331-4.

39. Nordenstrom J, Elvius M, Bagedahl-Strindlund M, Zhao B, Torring O. Biochemical hyperparathyroidism and bone mineral status in patients treated long-term with lithium. Metabolism. 1994;43:1563-7. 